\title{
IN SEARCH OF MISSING COLLECTION: THE CASE OF ARTIST ALBERT RAPPAPORT
}

\begin{abstract}
Summary. The artist Albert Rappaport was born in Anykščiai in 1898. In 1911, the family emigrated to New York. Rappaport became an American citizen in 1925 and began to travel widely. He studied fine art in New York, Paris, Dresden and Munich. He visited South America, Africa and traveled extensively through Europe (19251927, 1933, 1937-1939), returning to the United States now and again. The artist participated in several dozen exhibitions. He showed his work in Paris, Rome, Florence, Barcelona, Palma de Mallorca, Copenhagen, Mexico City, Havana, New York, Calgary and Montreal, in addition to his solo exhibitions in 1937 in Warsaw and Vilnius, and in Kaunas, Riga and Tallinn in 1938. After Rappaport's death, in March 17, 1969 in Montreal, his collection of artworks disappeared and has thus far not been found. To date, two of his painted portraits are known to exist one belongs to the private collection of Jonathan C. Rappaport, another is on display at the Jewish Public Library in Montreal.
\end{abstract}

Keywords: Albert Rappaport, Jewish art, lost art collection, Litvaks, shtetl, Anykščiai, Aniksht, Monreal, Harris Rappaport, Rochl Korn.

\section{INTRODUCTION}

Lithuania is the native land of many world-famous Jewish artists. During the $20^{\text {th }}$ century, many of them left Lithuania, scattering all over the world for various reasons. Some of them migrated by choice and went to study and seek glory in Western Europe, Paris and Berlin especially. Others sailed across the Atlantic voluntarily in search of a better life and work opportunities. Many were forced to flee for their own safety, looking for a safer place to hide from the wars, revolutions, anti-Semitism and Holocaust. Among Litvaks (Lithuanian Jews) émigré artists were Neemiya Arbit Blatas, Max Band, Victor David Brenner, Irving Norman, Ben Shahn, William Zorach and many others, who by the decree of fate found their new home in North America. ${ }^{1}$ All of them have their own life experiences and stories. They lived through the turbulent times and had a great impact on creating a new modern art in America as well as all world.

World War II and the Holocaust interrupted the development of Jewish art in Europe. The previously rich and multifarious Jewish art heritage of the interwar period was partially lost. The paintings, sculptures, watercolors, drawings, and sketches left in the artists' studios and homes either burned or disappeared, and only a tiny part of their work survives to this day. A number of lost art collections are still waiting to be found. The missing collections hide the rich and diverse Lithuanian cultural heritage; a case in point is the art collection of the littleknown Litvak artist Albert Benjamin Rappaport.

The study seeks to reconstruct the facts of Rappaport's biographical data, investigates his artistic life and concentrates in search for his lost art collection. It also explores his paths of migration and how the migration and new places shaped his identity and the art he produced. The attitudes of art critics and the public towards the art of Rappaport was also taken into consideration. By introducing the life and art of just one artist, the author of the article seeks to open a window on the once prosperous and destroyed world of the Lithuanian Jewish artistic life, as well as to fill some factual gaps in Lithuanian art history and to contribute in considering Lithuanian art to be 
a unified cultural space, where the artistic efforts of the multicultural communities merge.

The subject of research is entirely new. Rappaport's name is not mentioned in any book of Lithuanian or world art history; he is also unknown among the majority of art historians, critics and collectors, and his rich collection of paintings is thus far believed to be missing and waits to be discovered. In order to unravel the mystery of the life and art of Rappaport, reference has been made to different types of documents held at the Lithuanian State Historical Archives (LSHA) and the Kaunas Regional State Archives (KRSA), as well as the emigration and naturalization documents kept at the New York State Archives and the National Archives at New York City, which are available online at www.jewishgen. com, www.ancestry.com and www.familysearch. org. Searching for the lost works by Rappaport has led to cooperation with the Montreal Museum of Fine Arts, the Museum of Jewish Montreal and the Jewish Public Library in Montreal. This has in

\section{DAIL. ALBERTO B. RAPOPORTO}
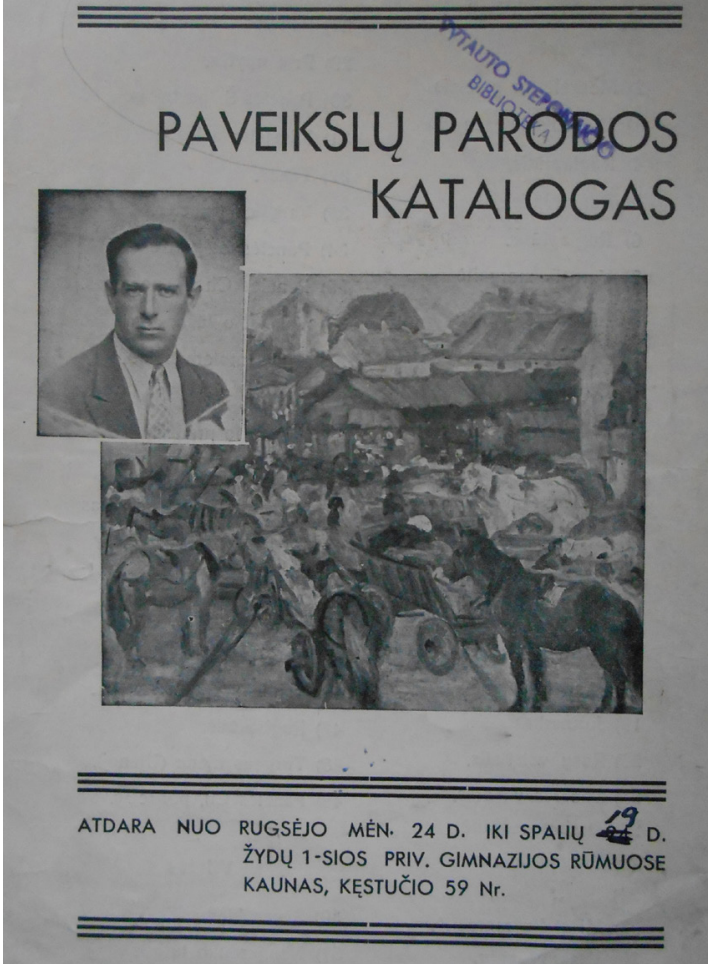

Fig. 1. The Catalogue of Exhibition of A. Rappaport, Kaunas, 1938. The Martynas Mažvydas National Library of Lithuania turn uncovered Rappaport's relatives who live in the United States - Mr. Jonathan C. Rappaport and Dr. Lawrence N. Rappaport. The author of the article would like to express her gratitude and appreciation to them for information and visual material that has assisted in reconstructing facts about the life and work of the artist Rappaport. I also thank the historians Rimantas Vanagas and Geršonas Taicas for their historical consultations.

Special attention was drawn to Rappaport's visit to Lithuania and the exhibitions he held in Vilnius and Kaunas between 1937-1938, therefore the research included the publications of the inter-war press released in Lithuanian, Yiddish, Polish and Russian held at the Martynas Mažvydas National Library of Lithuania, the Vrublevskis' Library of the Lithuanian Academy of Sciences and the Kaunas County Public Library. Newspapers in Yiddish contained the most information: the Lithuanian Jewish Education Society's newspaper Folksblat (People's Newspaper), the Lithuanian Jewish Zionist Organization's newspaper Di Yiddishe Shtime (Jewish Voice) and the unaffiliated newspaper Di Cait (Time). Montreal newspapers featured news about Rappaport's exhibitions in Canada in English, French and Yiddish, which are now kept at the Jewish Public Library in Montreal. I express my sincere thanks to the historian and translator Roza Bieliauskiene for her assistance in searching for material in Yiddish and for translating articles from Yiddish to Lithuanian. For the English translation of this article I thank the Lithuanian National Museum of Art and the translator Albina Strunga.

\section{FROM ANYKŠČIAI TO THE GLOBAL WORLD}

Uriel Boruch Rapoport was born on May 15, 1898 in Anykščiai (Aniksht). He was called Alter in the family. He was the second child of Yankel (1867-1946, son of Uriash) and Lea Dantsik/Denzeg (b. 1868, daughter of Girsh) Rapoport (renamed to Rappaport in United States). Aside from Urel, there was also his elder sister Nesa Gitliya (b. 1895) and two younger brothers - Chaim (b. 1901) and Elijash (b. 1905). ${ }^{2}$

Jews have been mentioned in Anykščiai ever since the second half of the $16^{\text {th }}$ century. ${ }^{3}$ According to the 
census conducted in 1897, the town had 2,754 Jews, or 69.7 percent of the total population. ${ }^{4}$ They mostly engaged in trade and the crafts, earning a name in the area for being good bricklayers, plasterers, painters, stove-builders and chimney-sweeps. Following extensive damage in the fires of 1891 and 1894, in the early $20^{\text {th }}$ century Anykščiai began to grow rapidly, becoming one of the largest cities in the Utena District. At the time when the Rappaport family lived in Anykščiai, the city had a post office and a telegraph station, a railway station, a town council, a police station, a hotel, a pharmacy with a medicine warehouse, several shops, a few breweries and taverns, a grape wine cellar, a state wine kiosk, a beer kiosk, a local teetotalers' society tea house and a hydroelectricity plant that started operating in 1902. Anykščiai was a multicultural city with the houses of prayer of various religions: a single-towered brick Roman Catholic church was built in 1757-1768 that was reconstructed into a larger neo-Gothic church in 1899-1909, and in 1867 the town's Russian Orthodox church was consecrated. ${ }^{5}$ The first synagogue is mentioned in the town's inventory documents in $1780,{ }^{6}$ while the second was built in $1784 .^{7}$ In the beginning of the $20^{\text {th }}$ century, the city had two synagogues and six Jewish houses of prayer and a mikva, with children attending the local cheder.

Several generations of the Rappaport (Rapoport) family lived in Anykščiai. The future artist's grandfather, Uriash (b. 1835, son of Boruch), participated in the Anykščiai Jewish community's activities and in voting, as his surname has been recorded in the rabbi electoral list. ${ }^{8}$ Urel's father Yankel was a stovebuilder, and even though the city was growing and he had plenty of work, it was difficult to earn enough to support his wife and four children. When searching for better paid work, in 1906 Yankel left his family and went to the United States, ${ }^{9}$ where his brothers Abraham and Hirsh (Harris) had already moved. In New York, Yankel found work as a plasterer, and as he was doing well, within five years he was able to bring his wife Lea and their children to live with him. They reached American shores on July 17, 1911 on the ship "Lituania". ${ }^{10}$ The official spelling of family name was written "Rappaport" on US documents. In order to make their integration into the new surroundings easier, the family changed their names: Yankel became Jacob, Lea became Lena, and the children's Litvak names gradually became Americanized: Nesa Gitliya became Netta, then Yetta and finally Jenny, Chaim became Hyman then Herman, Elijash became Izidor then Irving, while Uriel (Alter) - Albert. The second name of Boruch, which Albert had received to honor his great-grandfather, he changed to Benjamin. ${ }^{11}$

The Rappaport family settled in the Bronx area of New York. At this time, the Bronx was growing at a rapid pace and was popular for the many emigrants from Europe moving in. Irish, Italian and Polish communities formed, yet it was the Jewish community that was the largest - while World War II was raging in Europe, around half a million Jews made up almost 44 percent of the total population in the Bronx. ${ }^{12}$ The Litvak (Lithuanian Jews) community also grew; its younger generation would later earn fame not just for the many rabbis and scientists that emerged, but also its artists: the families of Victor David Brenner, Maurice Sterne and Samuel Halpert arrived in New York in 1890, followed by William Zorach and Max Weber in 1891, Ben Shahn and Morris Kantor in 1906, Albert Rappaport and Elias Mandel Grossman in 1911, Peter Blume in 1912, Mark Rothko's family in 1913, and so on. The youths were well acquainted, most of them gained their basic art education at the Educational Alliance Art School in Manhattan, which had been established by a Jewish organization that helped Jews from Eastern Europe settle down in New York.

Rappaport's drawing skills had been noticed at an early age, and in order to help his family financially, he would earn some extra money by writing signs and illustrating advertising stands for various shops, tailors, clothes and shoe repair services, cafes, bars and alike. The youth had particular success when the taxi fares would change in New York - he would spend hours rewriting the new tariffs on taxi car doors in neat handwriting. By doing this, he managed to save enough money for a trip to Europe. ${ }^{13}$

Albert Rappaport became a US citizen in $1925 .{ }^{14}$ Citizenship equalled relative freedom, and the young man was yearning to travel. He explored 


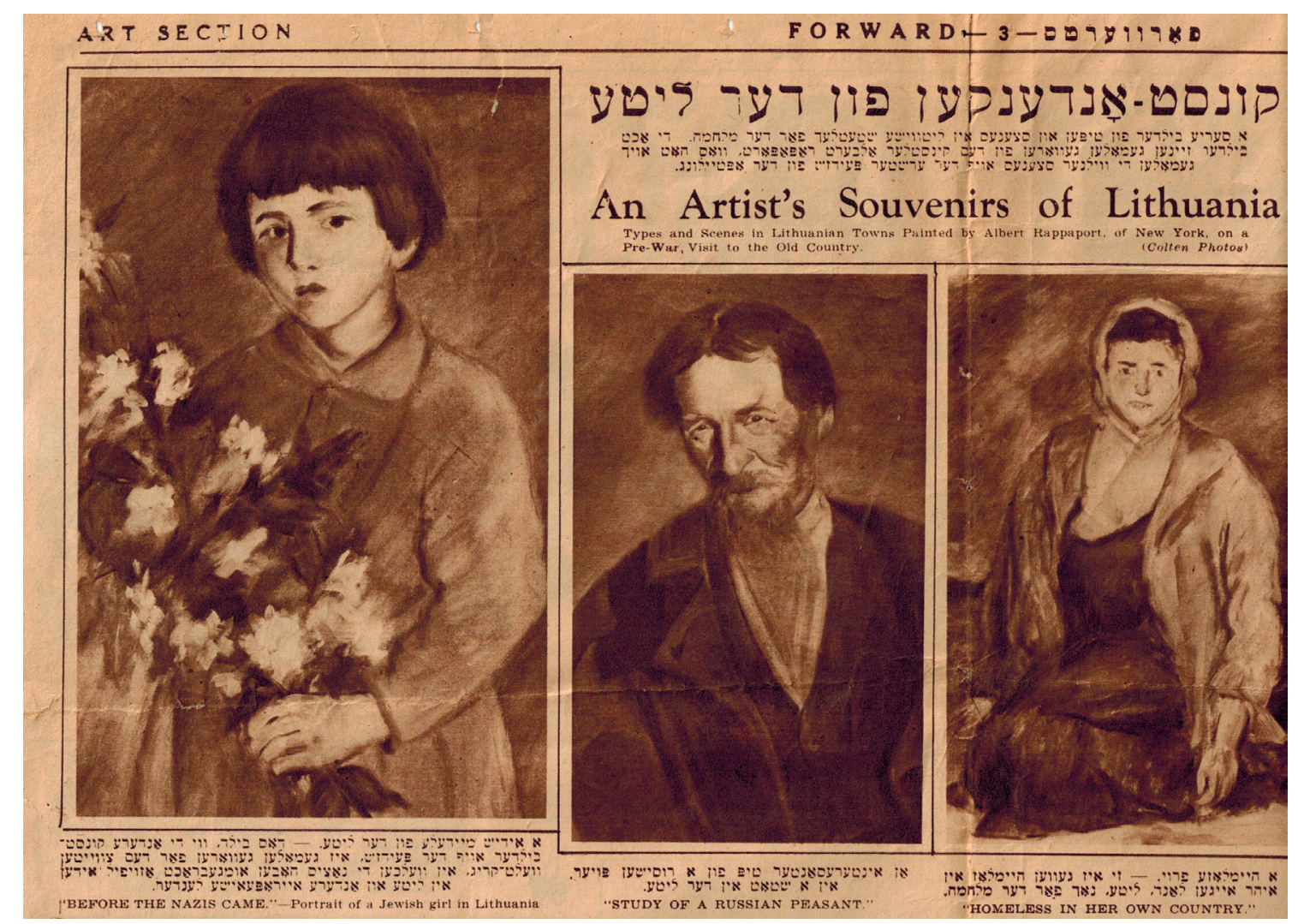

Fig. 2. A. Rappaport, Girl with Flowers (Before the Nazis Came), Russian Peasant (Study of A Russian Peasant), Homeless (Homeless in her Own Country). Photos from Forward, Sep 22, 1946, p. 3. Archive of Lawrence N. Rappaport

South America, Africa and Europe (1925-1927, 1933, 1937-1939), intermittently returning to the US, and also visited Mexico, Cuba, Morocco, Spain, Italy, Portugal, France, Poland, Latvia, Estonia and Lithuania (1938) before settling down in Canada in 1940. He studied art in New York, Paris, Dresden and Munich. The artist would earn money in various ways, mostly by creating advertising material and painting portraits: "Rappaport was very thrifty and could make money stretch and last a long time. He painted portraits for a living. In 1930, whilst staying in Mallorca, he received a commission to paint a portrait series of Italy's army generals". ${ }^{15}$

Rappaport participated in several dozen exhibitions. He showed his work at Galerie Zak and Salon d'Automne in Paris, also in Rome, Florence, Barcelona, Madrid, Lisbon, Palma de Mallorca, Moscow, Warsaw, Riga, Tallinn, Copenhagen, Mexico City, Havana, New York, Calgary and Montreal, and held exhibitions in Vilnius and Kaunas. ${ }^{16}$

\section{EXHIBITIONS, MAIN TOPICS AND PLASTIC EXPRESSION}

Even though Rappaport had the opportunity to become familiar with the most modern art trends of the day and the most innovative ideas, realism with a touch of light primitivism remained closer to his heart. ${ }^{17}$ This is evident from reproductions of the artist's work that appeared in the press.

In the winter and spring of 1937, Rappaport traveled around Poland and held an exhibition in Warsaw, while that summer and autumn was spent at the city of his birth Anykščiai and the Vilnius region where he painted landscapes and the local inhabitants. The artist held an exhibition in Vilnius on October 16-30, 1937 at the premises of the Vilnius Branch of the Polish Zionist Organization at 21 Vokiečiu Street. ${ }^{18}$ As the Di Cait correspondent noted, "the exhibition enjoyed high attendance and good reviews, some paintings were sold". ${ }^{19}$ It was the artist's portraits that left the greatest impression on art critics who came to his show. An article by an anonymous journalist "A.V." appeared in the press, 
in which Rappaport's typified portraits of a Lithuanian, Russian and a Jew were given a political tone:

Several portraits are probably the most noticeable in this exhibition that portray a number of nationalities and define the ethnic characteristics of the Lithuanian population. A Lithuanian peasant is a strong "fist" who backs the government in the Baltic States. He supports everyone who is in favor of unity and is opposed to revolutionaries. [...] He looks upon national minorities as hired labor and the idea that "my homeland is a country where your diaspora has settled" lies deep within his consciousness. Aside from the Lithuanian peasant, there is also a portrait of a Russian peasant at the exhibition. He is a minority in Lithuania, but the smile on his face shows that for now, he must keep his opinions to himself - no one knows what the future will bring, or who will end up being the actual master here. [...] The third portrait is of a Jewish trader. His windows are being smashed, he can be shoved around for no reason, or just for being a Jew. He feels that he is living in diaspora and this dictates his rules of behavior. This portrait reveals his helplessness in its entirety. [...] One may have various opinions of Albert Rapoport's work, but these portraits reveal the national situation in Lithuania that has formed through the course of history. ${ }^{20}$

The writer, journalist and director of the Solomon An-ski Museum of Jewish History and Ethnography, Elijah Jacob Goldschmidt, made the following remarks about the exhibition:

Being a child of his nation, Rapoport draws most attention to the life of his fellow countrymen, to the daily trials of Lithuanian townspeople. His drawings of typical characters emanate humanity, moral virtues and kindness. One needs only to see Rapoport's paintings - "An 80-year-old Jewish Blacksmith from Anykščiai", or "Feisele, the Scrounger of Anykščiai" to be immediately convinced that we are seeing the works of a Great artist, great with a capital ' $G$ '. Rapoport has held successful exhibitions in many cities across Europe that have brought him material gains. His exhibition in Vilnius is not intended to create a material profit but is more of an expression of his admiration for this city. ${ }^{21}$

Rappaport spent the summer of 1938 in Lithuania, travelling and visiting his relatives in Anykščiai. ${ }^{22}$ One of the artist's exhibitions was held at the Jewish Real Gymnasium in Kaunas (59 Kęstučio Street) between September 24 and October 14, 1938, where he displayed 84 works created in Lithuania, Poland, France, Spain, Italy, Portugal, Morocco and the United States - they included landscapes, architectural compositions, portraits and scenes of daily life. ${ }^{23}$ "Respected public figures attended the exhibition opening - writers, local artists and much of the intelligentsia. [...] They were left astounded by the artist's great diligence, he worked throughout the summer in our province, depicting market scenes, portraits and views of nature". 24 The Kaunas public found the exhibition interesting and it was extended

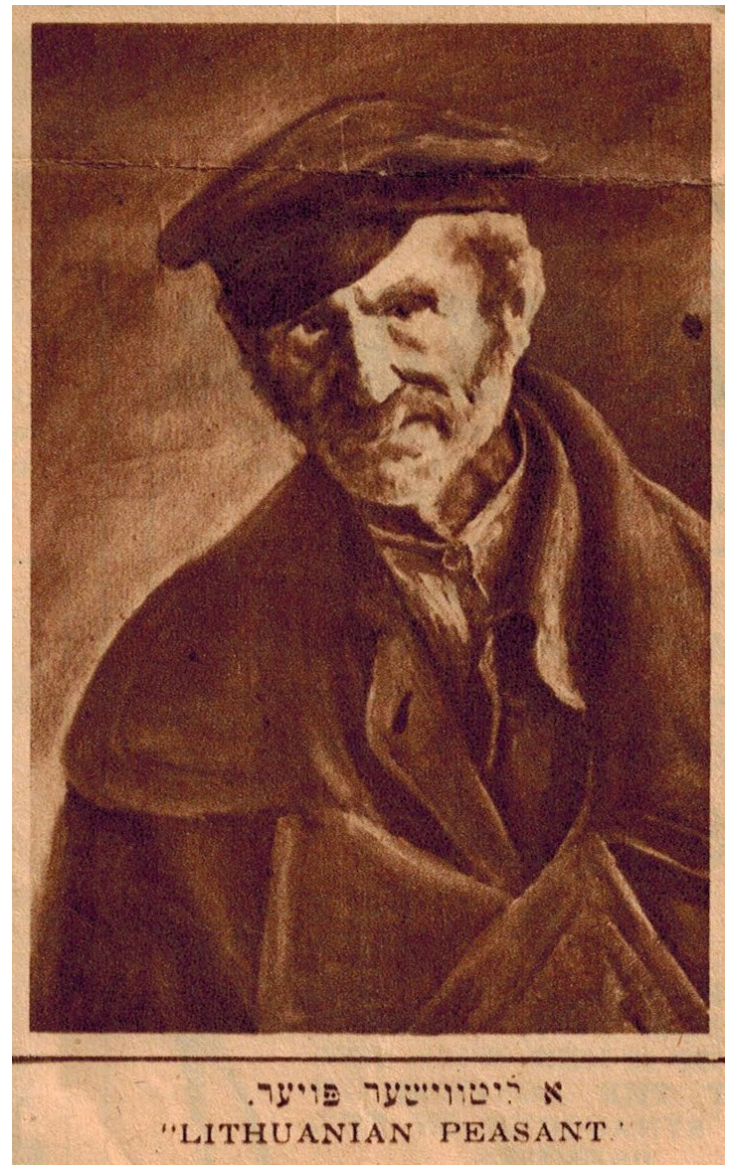

Fig. 3. A. Rappaport, Lithuanian Peasant. Photo from Forward, Sep 22, 1946, p. 3. Archive of Lawrence N. Rappaport 
until October 19. The Folksblat newspaper noted that "so as the Kaunas public could see his paintings, the artist voluntarily agreed to stay on in Kaunas for another several weeks". ${ }^{25}$

When visiting the place of his birth, Rappaport created a series of Lithuanian landscapes. The artist particularly liked to paint market scenes: Apple Market in Anykščiai, Market Day in Anykščiai (7 works), Fair, Spring Market, Market Day in Utena, Market on Naugarduko Street in Vilnius, Hales Market in Vilnius (3 works), Firewood Market in Vilnius (4 works). The author was also inspired by the daily life of Lithuanian Jews and Jewish character types: Coachman's Lodging, Wandering Pauper, Homeless, Girl-Worker, Jewish Girl, Synagogue Courtyard in Vilnius. ${ }^{26}$

In his commentary on Rappaport's exhibition in Kaunas, the art and culture critic Alfonsas Braziulis noted that the artist "was inclined to natural lyricism in his paintings. His works reflect the images and characters he has witnessed in the places he's visited, but mostly he depicts the Lithuanian landscape - quiet provincial towns, church villages and fields. A positive aspect of his work is the sense for reality, a dynamism gained from humanity, and the sensitive approach to harmony in color". ${ }^{27}$ The cultural figure and journalist Hirsh Abramovich also spotted Rappaport's inclination towards nature:

A. Rapoport is beguiled by Lithuania's nature, its way of life and characters from today's

Lithuania. He understands Lithuania's people

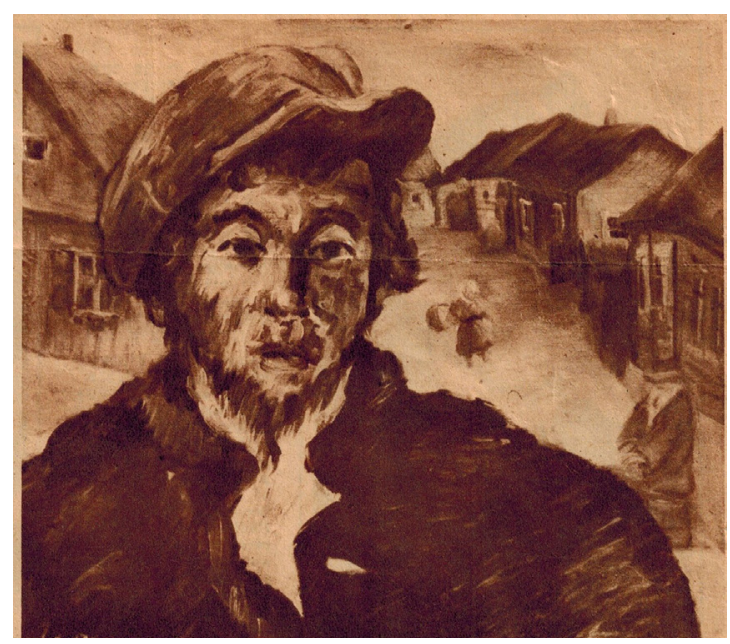

Fig. 4. A. Rappaport, Jewish Wanderer. Photo from Forward, Sep 22, 1946, p. 3. Archive of Lawrence

N. Rappaport quite unlike anyone else. His images of Lithuanian markets and fairs breathe with primitivism. Everything - the horses, wagons, livestock, market stalls, people, tables and all the other attributes - they all find their place in his paintings, creating pictures and characters of unexpected beauty. Rapoport's work is somewhat primitive and the images in his illustrations lie in juxtaposition to realistic life scenes in paintings, which imparts a sense of charm and originality to his work. The artist is certainly paving his own course in life, he does not abide by any school or art stream, he trusts only in his own free feelings and records everything he sees around him, what he feels and what he understands. That is why Rapoport's paintings are considered well-executed technically and are highly acclaimed in the art world. ${ }^{28}$

Estera Eljaševa-Veisbartiene, a famous Jewish cultural figure in interwar Kaunas, whose art research articles were willingly published by the Lithuanian press in different languages, dedicated a long piece to Rappaport's work that appeared in the Di Yiddishe Shtime newspaper. She wrote:

The artist Rapoport arrived in Anykšciai, the city of his birth, seeking new impulses in life. He chooses to be a primitivist and sees things in a naive way, as if witnessing them for the first time [...].

In his paintings, people and horses are full of lively expression, as if the creator has come into direct contact with everything, peeked in through every window, breathed in the smoke from every chimney and has participated in everything himself. Thus, the very rich colors in his paintings and the depth of imagery has an immediate effect on viewers. One gets the impression that the characters are about to step out of the frame and walk into the great, wide world. [...] His portraits drift from old-fashioned realism towards contemporary primitive paintings. He also creates cubist portraits... [...] The artist is best at depicting building compositions and natural landscapes, especially mountain-bound valleys with plants and birds, 
partly shielded from above by tree branches. His images of boats moving across the water painted en plein air are also very impressive. Rapoport is also skilled at conveying the Lithuanian color spectrum in his landscapes. [...] Yet most importantly, the way the author conveys emotions by using contemporary art methods arouses the interest and admiration of his exhibition audiences. ${ }^{29}$

Information gathered from newspaper articles suggests that following this exhibition in Kaunas, at the end of October, Rappaport went to Riga and Tallinn where he also held solo exhibitions. After this, he planned to go on to Paris, London and New York. ${ }^{30}$

Rappaport settled down in Montreal from 1940 where he became involved in the city's art circles. In April 1942, the artist held a solo exhibition in the art section of the T. Eaton Company store in Montreal.
He exhibited around 30 paintings which depicted the impressions he gained from his travels around Lithuania, Poland, Cuba and Mexico. The Lithuanian landscapes and market scenes deeply infused with the shtetl spirit appeared very interesting and exotic to visitors. Montreal's newspapers wrote about the exhibition, including the English-language publication Gazette. ${ }^{31}$

The famous Canadian public figure, journalist and translator Hannaniah Meir Caiserman, who had emigrated from Romania, mentioned Rappaport's exhibition in Canada's Yiddish newspapers Der Keneder Adler (The Canadian Eagle) and Dos Yiddishe Vort (The Jewish Word). ${ }^{32} \mathrm{He}$ particularly exalted the artist's color palette and his ability to create different moods in his paintings through color:

Half of Rappaport's paintings depict market scenes in Lithuania, Poland, Mexico and Cuba.

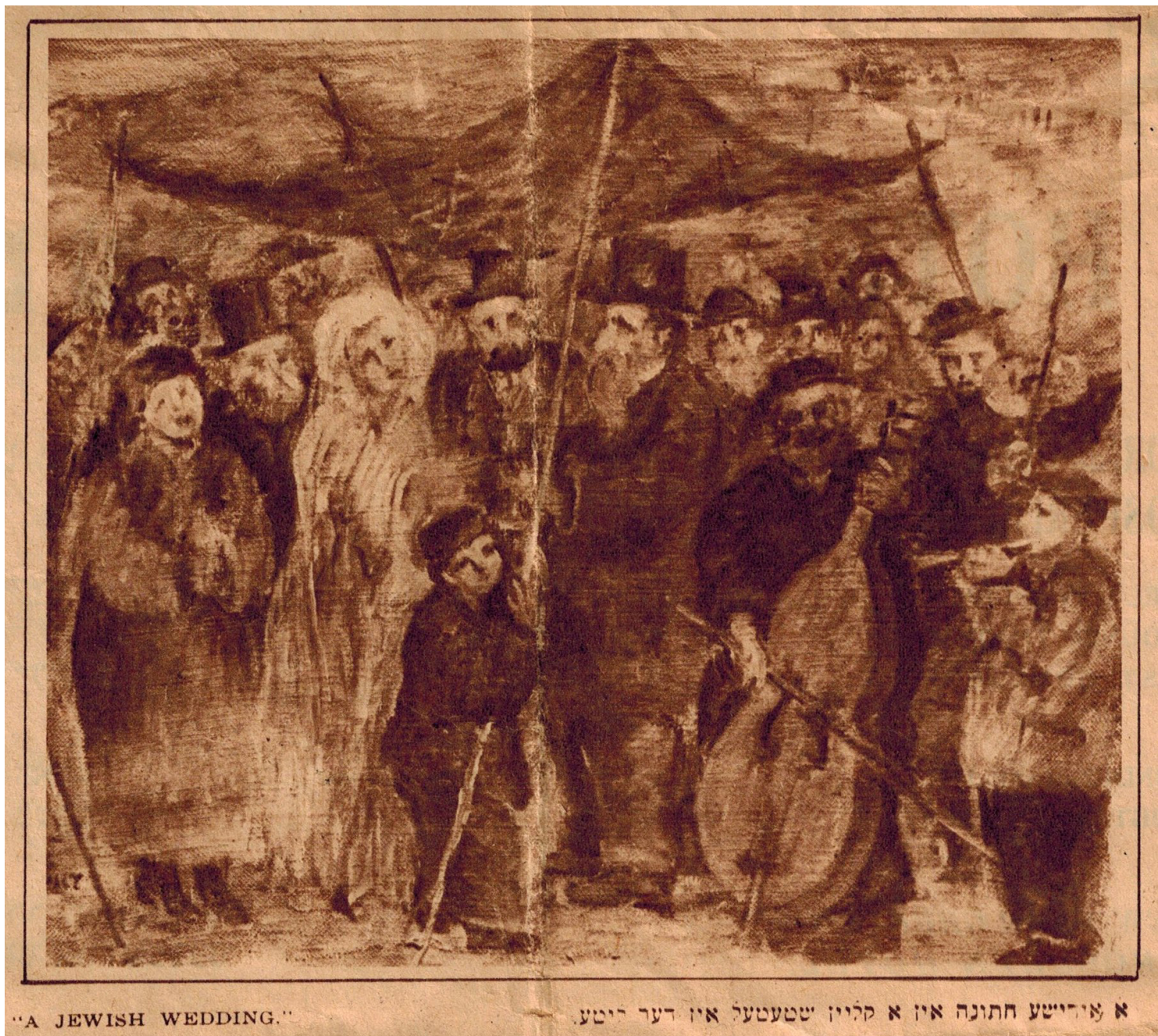

Fig. 5. A. Rappaport, A Jewish Wedding. Photo from Forward, Sep 22, 1946, p. 3. Archive of Lawrence N. Rappaport 
The painter uses various colors and creates harmonious and interesting compositions in almost every piece. For example, "Market Day in Mexico" sparkles with its yellow painted houses and red tile roofs, Mexican market traders seated on the ground in the shadow of green trees near the products they're selling, arranged in high piles. "Jewish Market in Poland in the Winter" takes place in the open air. Beets, fruit and vegetables placed on high tables, sleds piled with pottery, pitchers and pots. Wagons are hitched up to horses and are scattered across the market square with two-storied houses visible in the background. The grey-white palette of the painting conveys the freezing weather, while sketchy human figures have been created using light, pinkish strokes. A completely different mood spreads from the din and ruckus of "Market Day in Vilnius", which shows a colorful crowd of people amid the background of a street. ${ }^{33}$
Rappaport's last solo exhibition was held in February, 1965. Together with the sculptor and interior designer Jean Jacques Besner (1919-1993), he showed his paintings at the Montreal Museum of Fine Art's famous Gallery 12. The French Montrealbased newspapers Le Soleil (The Sun) and MontréalMatin (Montreal Morning) praised the show. ${ }^{34}$

Rappaport had married twice but had no children. ${ }^{35}$ He divorced his first wife Miriam in 1944 in Brevard County, Florida. ${ }^{36}$ His second wife Clara Schwartz (July 24, 1920-July 29, 1998) Rappaport married April 17, 1951 in Montreal. ${ }^{37}$ The artist died of cancer on March 17, 1969 in Montreal. He and his wife Clara are buried at the Baron de Hirsch Cemetery in Quebec. ${ }^{38}$

\section{CONCLUSION}

Various archive documents and periodical publications helped to reconstruct some important facts of Albert Rappaport's biography and to reveal his

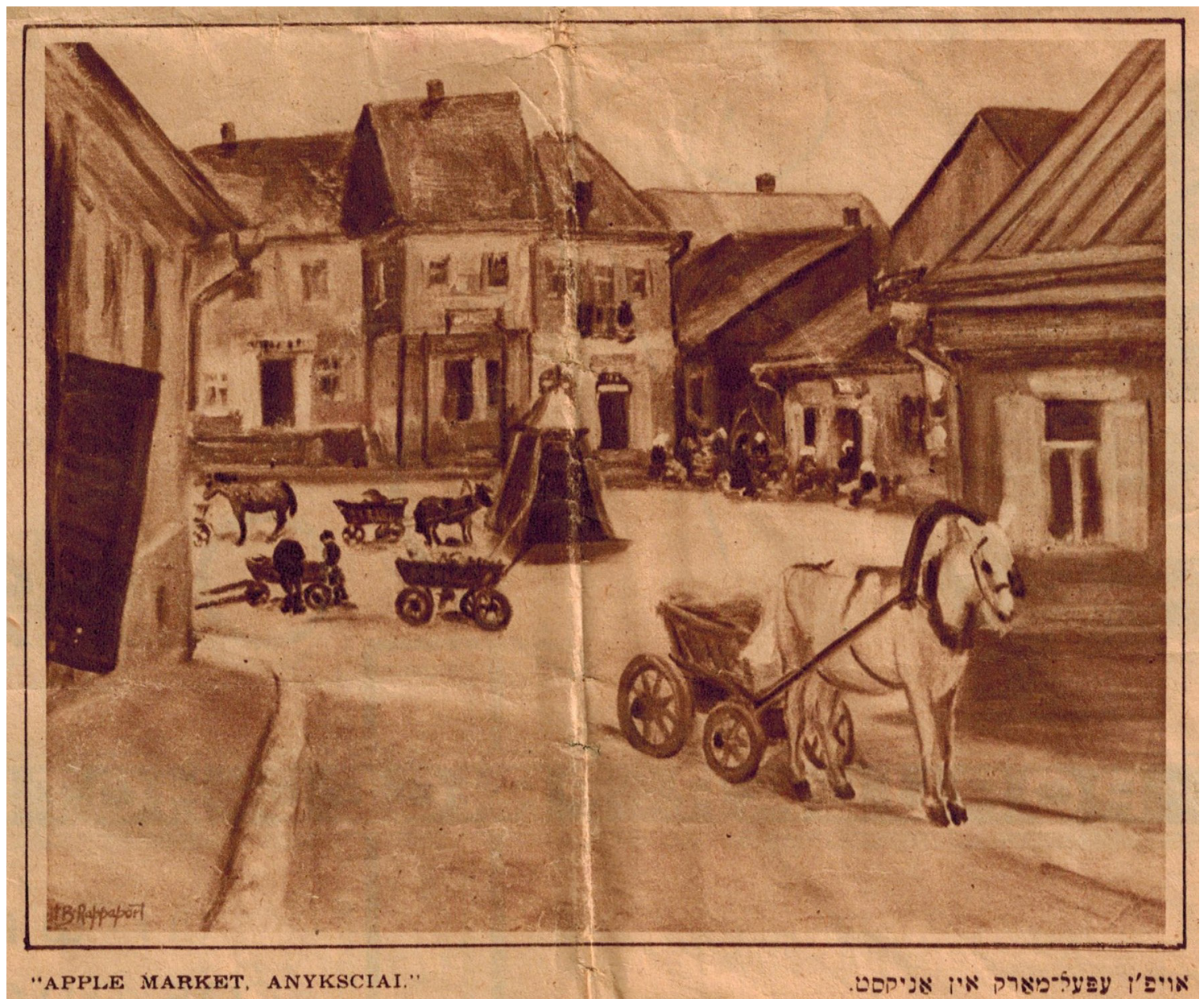

- $\quad$ Fig. 6. A. Rappaport, Apple Market in Anykščiai. Photo from Forward, Sep 22, 1946, p. 3. Archive of Lawrence N. Rappaport 
artistic life. At the beginning of the 20th century, the artist's family, as many other East European Jewish families, migrated to the US in search of a better life. However, Rappaport himself did not remain to live in one country. Living in Lithuania, US and Canada, visiting Mexico, Cuba, Morocco, Spain, Italy, Portugal, France, Poland, Latvia, Estonia and other countries he became a citizen of the world. His path as a traveler and as a migrant found a deep reflection in his art, both in themes and plastic expression colors in particular.

Art works and the collections of artists who emigrated from their homeland and spread around the world are gradually finding their way back to Lithuania's museums and private collections. Each year the Lithuanian National Museum of Art collection of émigré artists' works grows larger with the acquisition of art by Lithuanian Jews - Litvaks. Nonetheless, a number of lost collections are still waiting to be found, or perhaps even being returned to the art collections of Lithuania's museums. Unfortunately, the search for Rappaport's art collection is not very successful yet. Following Rappaport's death, his works of art disappeared and have thus far not been found. Rappaport spent the last twenty years of his life in Canada, therefore we can guess that the main

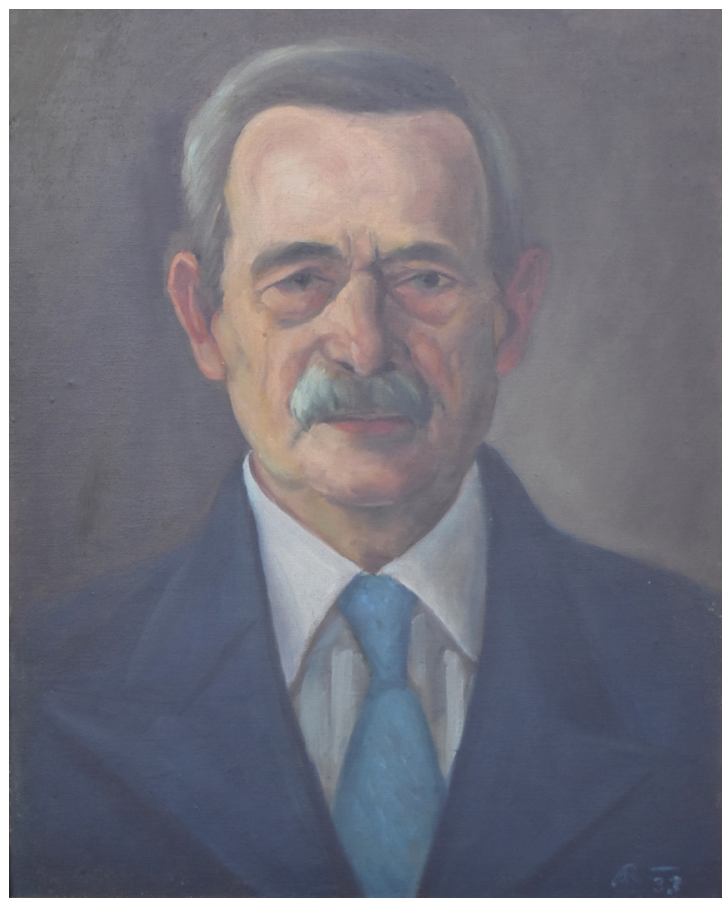

Fig. 7. A. Rappaport, Portrait Harris Rappaport, 1933, oil on canvas. Collection of Jonathan C. Rappaport location of the undiscovered collection is Montreal, the place, where the artist died.

During the research, two of Albert Rappaport's painted portraits were discovered. One of Albert's uncle Harris Rappaport painted in 1933, which is part of the private collection of Harris's grandson Jonathan C. Rappaport. Another portrait is of Rochl Korn (1898-1982), ${ }^{39}$ a female poet who wrote in Yiddish, painted in 1953 that is on display at the Jewish Public Library in Montreal.

A large part of the works of interwar Litvak artists is still unknown - many were destroyed during the World War II and the Holocaust, some are hidden in archives of different institutions and private collections and are still waiting for their discovery and evaluation. Therefore, the culture cooperation among different countries is of great importance to search for the lost collections as well as in reconstructing the biographies of artists, and in attributing and identifying their art works. Searching for the lost collection of works by Rappaport has led to close cooperation of the Lithuanian National Museum of Art with different kinds of institutions around the world, among them the Montreal Museum of Fine Arts, the Museum of Jewish Montreal and the

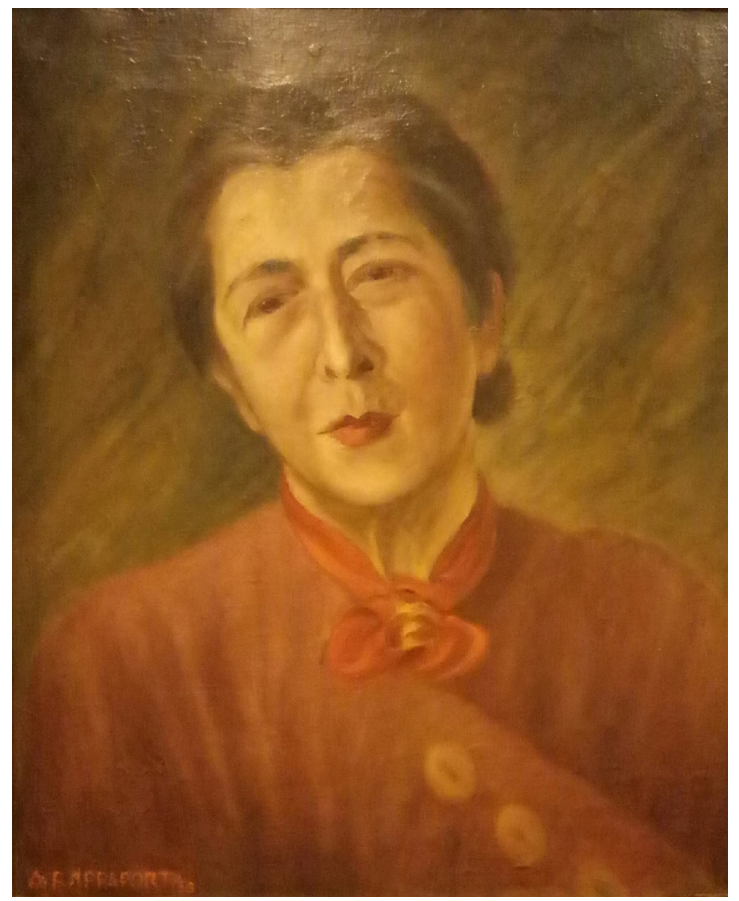

Fig. 8. A. Rappaport, Portrait of Rochl Korn, 1953, oil on canvas. The Jewish Public Library in Montreal 
Jewish Public Library in Montreal, as well as private collectors and relatives of the artist.

The search for lost art is potentially a powerful tool in keeping going the process of reflecting upon our history, cultural achievements and destiny of our heritage. Therefore, there is great value in exploring, discovering and augmenting the museums with new exhibits and collections. I have a hope that this research conducted by the Lithuanian National Museum of Art will help to track down the lost art of Albert Rappaport and reinstate his name in the pages of Lithuanian, US, Canadian and world art history.

\section{References}

"Cu der efenung fun Albert Rapoport bilder oysshtelung (At the opening of Albert Rapoport's painting exhibition)". Folksblat, 23 September 1938, 6.

"Di lang dervartene bilder oysshtelung (The long-awaited painting exhibition)". Di Cait, 14 October 1937, 4.

"Faierlehe derefenung fun A. Rapoports bilder oysshtelung (Ceremonial opening of Rapoport's painting exhibition)". Folksblat, 30 September 1938, 3.

"Fun Alberts Rapoports bilder - oysshtelung (Opening of Albert Rapoport's painting exhibition)”. Di Cait, 08 October 1937, 4.

"Geefnt oysshtelung fun kinstler Rapoport (Artist Rapoport's exhibition has opened)". Di Yiddishe Shtime, 25 September 1938, 8.

"Geshlosn di oysshtelung fun A. Rapoport' (A. Rapoport's exhibition ends)". Di Cait, 01 November 1937, 4.

"Jacques Besner et Albert Rappaport exposent au Musée des Beaux-Arts". Le Soleil, 06 February 1965, 4.

"Kinstler A. Rapoport in Kaunas (Artist A. Rapoprt in Kaunas)". Folksblat, 20 September 1938, 6.

"Kinstler Albert Rapoport kumt kein Talin (Artist Albert Rapoport arrives in Tallinn)". Di Yiddishe Shtime, 27 October 1938, 2.

"Sculpture et peinture au Musée des Beaux-Arts de Montréal". Montréal-Matin, 08 February 1965, 4.

“Travelled Painter Holding Exhibition. Albert Rappaport Shows Scenes in Lithuania, Cuba and Mexico at Eaton's". Gazette, 04 April 1942, 3.

1877 Tax Payers List: Uriash Rapoport, son of Boruch. KRSA, col. I-49, inv. 1, f. 12938, p. 309

1897 Kaunas Province Population Census. LSHA, col. 768, inv. 1, f. 31 .

1944 Brevard, Florida Divorce Index 1927-2001, vol. 253, certificate 4584, www.ancestry.com [accessed 22.09.2020].

A.V. "Drai portretn (cu der oysshtelung fun A. Rapoport) (Three portraits (at A. Rapoport's exhibition)". Di Cait, 24 October 1937, 2.
Abramovich, Hirsh. "Cu Albert Rapoports oysshtelung (At Albert Rapoport's exhibition)". Folksblat, 13 October 1938, 5 .

Albert Benjamin Rappaport, U.S. Petition for Naturalization No 59356, 13.03.1925, New York, USA Passport 423187 issued 09 July 1925 Southern District Court, New York, NY, National Archives at New York City, page 906, www.ancestry.com [accessed 10.09.2020].

Braziulis, Alfonsas. "A. Rapoporto paroda". Trimitas 40 (1938): 971

Caiserman, Hannaniah Meir. "A vikhtige bilder oysshtelung fun a gast moler - Albert Rappaport (An important picture exhibition by a guest painter - Albert Rappaport)". Der Keneder Adler, 17 April 1942, 4.

Caiserman, Hannaniah Meir. "Vikhtiker idisher moler in mairei Kanade (Significant Jewish artist in west Canada)". Dos Yiddishe Vort, 26 November 1942, 4.

Correspondence between Dr. Lawrence N. Rappaport and Mr. Jonathan C. Rappaport. Email dated 11.07.2020.

Dail. Alberto B. Rapoporto paveikslu parodos katalogas. Kaunas, 1938.

Electoral List for the Anykščiai Rabbi, 20.11.1891: Uriash Rapoport, son of Boruch, KRSA, col. I-49, inv. 1, f. 16601, p. 17.

Eljashev, Estera. "Albert Rapoports oysshtelung (in Hebreishe real-gimnazoje) (Albert Rapoport's exhibition (at the Hebrew real gymnasium)". Di Yiddishe Shtime, 13 October 1938, 4.

Ellis Island, RMS “Etruria” from Liverpool, 23.06.1906. List or Manifest of Alien Passengers for the U.S. Immigration Officer at Port of Arrival, National Archives at New York City, page 6, line 28, www.ancestry.com [accessed 29.10.2020].

Ellis Island, SS "Lituania" from Libau, 17.07.1911. List or Manifest of Alien Passengers for the U.S. Immigration Officer at Port of Arrival, National Archives at New York City, page 9, lines 26-30, www.ancestry.com [accessed 29.10.2020].

Exhibition of Works by Canadian Jewish Artists at the Montreal Museum of Fine Arts, October 29 to November 15. Canadian Jewish Congress, 1959.

Goldshmit, Elijah Jakov. "Cu der bilder-oysshtelung fun dem kinstler Albert Rapoport (At the opening of artist Albert Rapoport's painting exhibition)". Di Cait, 15 October 1937, 2.

Irvine, Eastman, ed. The World Almanac and Book of Facts. New York World-Telegram, 1943.

Jučas, Mečislovas, ed. Lietuvos TSR urbanistikos paminklai 3. Vilnius: Mokslas, 1979.

List of Voters from Anykščiai: Uriash Rapoport, son of Boruch. LSHA, col. 1567, inv. 1, f. 2285, p. 3, 12

Miškinis, Algimantas. Lietuvos urbanistikos paveldas ir jo vertybes 2. Vilnius: Petro ofsetas, 2005.

Naturalization Records 1882-1944, New York, www. ancestry.com [accessed 16.10.2020]; State and Federal Naturalization Records 1794-1943, New York, www. ancestry.com [accessed 16.10.2020]. New York State Census 1915, New York State Archives, lines 39-44, www.familysearch.org [accessed 17.10.2020];

New York State Census, 1930, New York State Archives, lines 7-9, www.familysearch.org [accessed 17.10.2020].

Račkaitis, Vygandas, Verbickas, Antanas, eds. Anykščiai: istorijoje, literatūroje, atsiminimuose. Vilnius: Mintis, 1992. 
Vanagas, Rimantas, Vanagas, Nerijus. Anykščiu fenomenas. Vilnius: Petro ofsetas, 2016.

Бершадскій, Сергей А. Русско-еврейскій архивъ. Документы и регесты къ исторій титовскихь евреевъ 1. С. Петербургъ, 1882.

Градинскайте, Вильма. "Влияние художниковлитваков на американское искусство”. Цайтшрифт, 6 (11). Минск-Вильнюс (2019): 199-209.

\section{Notes}

1 For more information, see: Вильма Градинскайте, "Влияние художников-литваков на американское искусство”, Цайтшрифт 6 (11) (Минск - Вильнюс, 2019), 199-209.

21897 Kaunas Province Population Census, LSHA (Lithuanian State Historical Archives), col. 768, inv. 1, f. 31.

3 The first time Jews were mentioned in Anykščiai was in 1567 when Joachim, the son of Shaya, accused the Anykščiai District voigt Valentinas Buivydas that his two brothers and son-in-law were killed at his tavern. The murderers admitted that the voigt had talked them into raiding the tavern and killing the Jews. See: Сергей A. Бершадскій, Русско-еврейскій архивъ. Документы и регесты къ исторій литовскихъ евреевъ 1 (С. Петербургъ, 1882), 200.

1897 Kaunas Province Population Census, LSHA, col. 768 , inv. 1, f. 31 .

5 For more information about Anykščiai, see: Anykščiai: istorijoje, literatūroje, atsiminimuose, eds. Vygandas Račkaitis and Antanas Verbickas (Vilnius: Mintis, 1992); Rimantas Vanagas, Nerijus Vanagas, Anykščiu fenomenas (Vilnius: Petro ofsetas, 2016).

6 Algimantas Miškinis, Lietuvos urbanistikos paveldas ir jo vertybès 2 (Vilnius: Petro ofsetas, 2005), 692.

Lietuvos TSR urbanistikos paminklai 3, ed. Mečislovas Jučas (Vilnius: Mokslas, 1979), 29.

81877 Tax Payers List: Uriash Rapoport, son of Boruch, KRSA (Kaunas Regional State Archives), col. I-49, inv. 1, f. 12938, p. 309; List of Voters from Anykščiai: Uriash Rapoport, son of Boruch, LSHA, col. 1567, inv. 1, f. 2285, p. 3, 12; Electoral List for the Anykščiai Rabbi, 20.11.1891: Uriash Rapoport, son of Boruch, KRSA, col. I-49, inv. 1, f. 16601, p. 17.

$9 \quad$ Ellis Island, RMS “Etruria” from Liverpool, 23.06.1906. List or Manifest of Alien Passengers for the U.S. Immigration Officer at Port of Arrival, National Archives at New York City, page 6, line 28, accessed 29.10.2020, www.ancestry.com.

10 Ellis Island, SS "Lituania" from Libau, 17.07.1911. List or Manifest of Alien Passengers for the U.S. Immigration Officer at Port of Arrival, National Archives at New York City, page 9, lines 26-30, accessed 29.10.2020, www.ancestry.com.

11 Naturalization Records 1882-1944, New York, accessed 16.10.2020, www.ancestry.com; State and Federal Naturalization Records 1794-1943, New York, accessed 16.10.2020, www.ancestry.com; New York State Census 1915, New York State Archives, lines 39-44, accessed
17.10.2020, www.familysearch.org; New York State Census, 1930, New York State Archives, lines 7-9, accessed 17.10.2020, www.familysearch.org.

12 The World Almanac and Book of Facts, ed. Eastman Irvine (New York World-Telegram, 1943), 494.

13 Correspondence between Dr. Lawrence N. Rappaport and Mr. Jonathan C. Rappaport. Email dated 11.07.2020.

14 Albert Benjamin Rappaport, U.S. Petition for Naturalization No 59356, 13.03.1925, New York, USA Passport 423187 issued 09 July 1925 Southern District Court, New York, NY, National Archives at New York City, page 906, www.ancestry.com [accessed 10.09.2020].

15 Correspondence between Dr. Lawrence N. Rappaport and Mr. Jonathan C. Rappaport. Email dated 11.07.2020.

16 Exhibition of Works by Canadian Jewish Artists at the Montreal Museum of Fine Arts, October 29 to November 15 , (Canadian Jewish Congress, 1959), exhibition catalogue.

17 Dr. Lawrence N. Rappaport recalls that the artist also painted abstract compositions, however so far no works in this style have been found. Correspondence between Dr. Lawrence N. Rappaport and Mr. Jonathan C. Rappaport. Email dated 11.07.2020.

18 "Di lang dervartene bilder oysshtelung (The long-awaited painting exhibition)", Di Cait (14 October 1937), 4; "Fun Alberts Rapoports bilder - oysshtelung (Opening of Albert Rapoport's painting exhibition)", Di Cait (08 October 1937), 4.

19 "Geshlosn di oysshtelung fun A. Rapoport' (A. Rapoport's exhibition ends)”, Di Cait (01 November 1937), 4.

20 A.V., "Drai portretn (cu der oysshtelung fun A. Rapoport) (Three portraits (at A. Rapoport's exhibition)", Di Cait (24 October 1937), 2.

21 Elijah Jakov Goldshmit, "Cu der bilder-oysshtelung fun dem kinstler Albert Rapoport (At the opening of artist Albert Rapoport's painting exhibition)", Di Cait (15 October 1937), 2.

22 "Geefnt oysshtelung fun kinstler Rapoport (Artist Rapoport's exhibition has opened)", Di Yiddishe Shtime (25 September 1938), 8.

23 " $\mathrm{Cu}$ der efenung fun Albert Rapoport bilder oysshtelung (At the opening of Albert Rapoport's painting exhibition)", Folksblat (23 September 1938), 6.

24 "Faierlehe derefenung fun A. Rapoports bilder oysshtelung (Ceremonial opening of Rapoport's painting exhibition)", Folksblat (30 September 1938), 3.

25 "Kinstler A. Rapoport in Kaunas (Artist A. Rapoport in Kaunas)", Folksblat (20 September 1938), 6.

26 Dail. Alberto B. Rapoporto paveikslu parodos katalogas (Kaunas, 1938).

27 Alfonsas Braziulis, "A. Rapoporto paroda”, Trimitas 40 (1938), 971.

28 Hirsh Abramovich, "Cu Albert Rapoports oysshtelung (At Albert Rapoport's exhibition)”, Folksblat (13 October 1938), 5.

29 Estera Eljashev, "Albert Rapoports oysshtelung (in Hebreishe real-gimnazoje) (Albert Rapoport's exhibition (at the Hebrew real gymnasium)", Di Yiddishe Shtime (13 October 1938), 4.

30 "Kinstler Albert Rapoport kumt kein Talin (Artist Albert Rapoport arrives in Tallinn)", Di Yiddishe Shtime (27 October 1938), 2.

31 "Travelled Painter Holding Exhibition. Albert Rappaport Shows Scenes in Lithuania, Cuba and Mexico at Eaton's", Gazette (04 April 1942), 3. 
؛ 32 Hannaniah Meir Caiserman, "Vikhtiker idisher moler in mairei Kanade (Significant Jewish artist in west Canada)", Dos Yiddishe Vort (26 November 1942), 4.

33 Hannaniah Meir Caiserman, "A vikhtige bilder oysshtelung fun a gast moler - Albert Rappaport (An important picture exhibition by a guest painter - Albert Rappaport)", Der Keneder Adler (17 April 1942), 4.

34 "Jacques Besner et Albert Rappaport exposent au Musée des Beaux-Arts”, Le Soleil (06 February 1965), 4; "Sculpture et peinture au Musée des Beaux-Arts de Monréal” (Montréal-Matin, 08 February 1965), 4.

35 Dr. Lawrence N. Rappaport says that Albert Rappaport had a descendant in Spain, yet there is no knowledge of him. Correspondence between Dr Lawrence
N. Rappaport and Dr Jonathan C. Rappaport. Email dated 11.07.2020.

361944 Brevard, Florida Divorce Index 1927-2001, vol. 253, certificate 4584, www.ancestry.com [accessed 22.09.2020].

37 April 17, 1951 Montreal, Marriage Certificate of Albert Rappaport and Clara Schwartz, https://www. genealogiequebec.com/blog/en/2017/10/02/marriages-and-deaths-1926-1997/ [accessed 18.11.2020].

38 Photo of grave of Albert Rappaport, www.findagrave. com/memorial/60984074/albert-b-rappaport; Photo of grave of Clara Rappaport, www.findagrave.com/memorial/60984315/clara-rappaport [accessed 16.11.2020].

39 Rochl Korn was born in Galicia (in the territory of present-day Ukraine). She fled to Uzbekistan in June, 1941 before emigrating to Canada in 1948.

Vilma GRADINSKAITE்

Lietuvos nacionalinis dailès muziejus, Vilnius, Lietuva

\section{DINGUSIOS KOLEKCIJOS PAIEŠKOS: DAILININKO ALBERTO RAPPAPORTO ATVEJIS}

\section{Santrauka}

Palaipsniui i Lietuvos muziejus ir privačius rinkinius grịžta iš gimtinès emigravusių ir po pasauli pasklidusių dailininkų pavieniai darbai ir kolekcijos. Kasmet gausèja Lietuvos nacionalinio dailès muziejaus dailininkų išeivių kūrybos fondas, pasipildantis ir Lietuvos žydų (litvakų) dailininkų darbais. Vis dèlto nemažai dingusių kolekcijų dar tik laukia, kol bus atrastos, o galbūt net sugrị̌s i Lietuvos muziejų dailès fondus. Užmarštyje skendi ir Lietuvoje nežinomo litvako dailininko Alberto Benjamino Rappaporto (1898-1969) iš Anykščių biografija ir kūryba, o gausi jo tapybos darbų kolekcija kol kas dingusi be žinios. Siekiant išnarplioti dailininko A. Rappaporto gyvenimo ir kūrybos gijas, bendradarbiauta su Lietuvos, JAV ir Kanados archyvais, bibliotekomis ir muziejais bei dailininko giminaičiais, remtasi periodine spauda jidiš, lietuvių, prancūzų ir anglų kalbomis.

Reikšminiai žodžiai: Albertas Rappaportas, žydų dailè, dingusios meno kolekcijos, litvakai, štetlas, Anykščiai, Monrealis, Harris Rappaport, Rochl Korn.

\section{Vilma GRADINSKAITĖ}

$\mathrm{PhD}$ Vilma Gradinskaite is a researcher and curator at Lithuanian Diaspora Art Museum, Lithuanian National Museum of Art. The main field of research is the cultural heritage of non-Christian Lithuanian minorities - Jews, Karaites and Tatars. She is a specialist in Eastern European Jewish art, regularly gives lectures and presentations at international congresses, conferences and seminars, and is the author of over

forty articles in Lithuanian, English and Russian and several books: "Lithuania in Litvak Arts" (2018), "Litvak Art in Private Lithuanian Collections" (2015), "Shalom, Israel! The Paths of Litvak Artists” (2015), "Hello Paris! The Paths of Litvak Artists (2014)" and others.

E-mail: vilmagrad@yahoo.com. 